\title{
ON THE GENUS MYLIA S. GRAY (HEPATICAE, JUNGERMANNIACEAE, MYLIOIDEAE)
}

\section{O POДЕ MYLIA S. GRAY (HEPATICAE, JUNGERMANNIACEAE, MYLIOIDEAE)}

\author{
AlEXeY D. POTEMKIN ${ }^{1}$ and SERGEY G. KAZANOVSKY² \\ АЛЕКСЕЙ Д. ПОТЕМКИН ${ }^{1}$ И СЕРГЕЙ Г. КАЗАНОВСКИЙ
}

Abstract

\begin{abstract}
A valid separation of the genus Mylia into two sections, Anomalae Schust. ex Potemk. and Mylia (- section Verrucosae Schust. nom. invalid. et illeg.), is carried out. Distinguishing characters of the species of Mylia, section Mylia, the distribution of $M$. taylorli and $M$. verrucosa and taxonomical status of $M$. nuda, are reviewed on the base of a comparative investigation. Key to recognized taxa of the genus is presented.
\end{abstract}

Резиоме

Пересмотрены хритерии для различения видов типовой сехции рода Mylia, $M$. taylorii и $M$. verrucasa, а также тахсономический статус фпонско-тайванского вида $M$. пuda, который отнесен х $M$. vетrисоза в качестве особого подвида. Обсухдактся диагностические признаки видов, дан ключ для определения. Уточненя номенклатура внутриродового деления рода - действительно обнародована секция Anomalae Schust. ex Potemk.

\section{INTRODUCTION}

The genus Mylia S. Gray s. str. includes four species distributed in Holarctic and adjacent regions. It is divided into two natural groups: 1) section Anomalae Schust. ex Potemk. ( = section Anomalae Schust. 1959. Amer. Midl. Nat. 62:35, nom. invalid., descr. angl.: Cuticula laevis; guttae olei grosse segmentata; folia gemmipara protracta, lanceolata, in apicem valde angustata. Sectionis typus: Mylia anomala (Hook.) S. Gray.) with one species, $M$. anomala (Hook.) S. Gray, which has smooth cuticle, coarsely segmented oil-bodies and elongate, lanceolate, narrowed to apex gemmiparous leaves, and 2) section Mylia (- section Verrucosae Schust. 1959. Amer. Midl. Nat. 62:36, nom. invalid. et illeg., incl. typo generis). The section Mylia includes three species: the generitype - M. taylorii (Hook.) $S$. Gray, $M$. verrucosa Lindb. and $M$. nuda $H$. Inoue \& Yang. They are characterized by coarsely papillous cuticle, finely granulated oil-bodies and unmodified (i.e. similar to other leaves in shape), never considerably narrowed to apex, gemmiparous leaves. This paper is concerned mainly with the species of the latter section.

The present study was initiated by a collection from Khamar-Daban Range, southern Baikal Region, South Siberia, which consists of a number of problematic specimens of Mylia, section Mylia.

The plants in question are plagiotropic, growing usually on decaying wood, and have more or less lingulate leaves with mostly yellow brown secondary pigmentation - a characteristic features noted in previous Russian treatments for $M$. verrucosa

I - Russia 197376 St.-Petersburg, Prof. Popova str., 2, Botanical Institute of Russian Acad. Sci. (Poccug 197376 Санкт-Петербург, проф. Попова, 2, Ботанический институт РАН).

2 - Russia 664033 Irkutsk, P.O.Box 1243, Siberian Inst. of Plant Physiol. \& Biochem. of Russian Acad. Sci. (Poccha 664033 Иркутск, a/s 1243, СИФИБР РАН). 
(Ladyzhenskaja \& Zenkova 1955; Schljakov 1982). On the other hand, these problematic plants do not develop echinate, but smooth, perianth - a diagnostic feature of the two other species of the section - namely, the widespread $M$. taylorii and the Taiwanese and South Japanese (Yakushima I.) $M$. nuda. The descriptions of $M$. verrucosa and $M$. nuda in M. Hara (1956), H. Inoue \& B. Yang (1966), J. Vana \& H. Inoue (1983) include other feature, such as incurved (Inoue \& Yang 1.c.; Vana \& Inoue 1.c.) or involuted backward (Hara l.c.) dorsal leaf margin. Interestingly, incurved dorsal leaf margin was noted in our plants only on male bracts. Since this last feature was often not consistently illustrated in different treatments, we could not form a definite opinion about its taxonomic significance. These facts led us to make a comparative investigation of the three species of Mylia in section Mylia, in order to elucidate the taxonomical identity of plants collected from Khamar-Daban Range, and also to clarify the geographical distribution of $M$. taylorii, $M$. verrucosa and M. nuda.

COMPARISON OF MYLIA TAYLORI, $M$. VERRUCOSA AND $M$. NUDA

On the basis of a critical study of specimens and data taken from literature (Gray 1821; Hara 1956; Inoue \& Yang 1966; Ladyzhenskaja \& Zenkova 1955; Lindberg 1872; Schljakov 1982; Schuster 1959, 1969; Vana \& Inoue 1983) the morphological differences of these three species are tabulated (Tab. 1) and their constancy as distinguishing features is discussed below.

Leaf form. Leaf form is an important distinctive feature of the species. Although width/length leaf ratio varies greatly (Tab. 1) and depends apparently on a complex interaction of different ecological factors such as intensity of insolation, soil nourishment, water supply, etc., some peculiarities of leaf form appear constant. Dorsal leaf margin of sterile leaves of $M$. taylorii is invariably plane (Figs. 1,3-7,9). Only on male bracts it is somewhat incurved. In $M$. verrucosa, as well as in $M$. nuda, it is strongly incurved or pipe-like involuted backward (Figs. 20,23). This feature gives the plants of these two species a very peculiar appearance. Leaves of $M$. taylorii have oppositely curved, or as an exception, straight subparallel margins in basal halves (Figs. 3-7). In the other two species, the leaf margins are subparallel, usually somewhat falcately curved (Figs. 13-15,18), and are never considerably curved in opposite directions. The data on the variability of ventral leaf margins of the species concerned are somewhat different. In $M$. taylorii it is usually smooth or faintly crenulate by the projecting of marginal cells (Fig. 8). In $M$. verrucosa this feature varies from smooth to distinctly crenulate (Fig. 19), and in $M$. nuda - to coarsely crenulate (Fig. 22). Because of considerable overlapping of the range of variability, this criterion can not be used as a reliable distinctive feature.

Secondary pigmentation. All species of the section are characterized by broad variability of secondary pigmentation. The most variable species in this respect is $M$. taylorii. While Schuster $(1959,1969)$ stresses that American plants of the species are "almost invariably carmine red to purplish brown pigmented at least on distal parts of upper leaves even when growing in very diffuse light ... never the warm brown of the related M. anomala", this statement is not quite correct. Green and yellow brown plants of $M$. taylorii occur rather often in Europe and Asia (see the list of examined specimens). The purplish pigmentation is characteristic of plants of exposed habitats. It results obviously from intense insolation. However, this pigment is unstable and in shade it is replaced by yellow brown pigment. Orthotropic plants of $M$. taylorii growing in dense mats in insolated places have purplish or purplish brown upper leaves and yellow brown lower ones. Secondary pigmentation of $M$. verrucosa and $M$. nuda is mostly yellow brown. Only ventral bases of male bracts and underleaves, more rarely of sterile leaves, are purplish brown or purplish. S.O. Lindberg (1872) also noted the often occurrence of purplish pigmentation on the basal part of perianth. Purplish brown pigmentation of 
TABle 1. COMPaRison OF THE SPECIES OF THE GENUS MYLIA, SECTION MYLIA.

Character

M. taylorii

Leaf form

suborbicular to oblong, obcordate and oblong-lingulate (the lower halves of leaves as a rule with oppositely curved sides)

Width/length

leaf ratio

\section{Dorsal leaf} margin

Ventral leaf margin at base

\section{Secondary} pigmentation-

Perianth surface smooth

Perianth mouth

Cilia

Male bracts

Number of epi-

dermal cell

rows of seta

Capsule wall

Cells of epidermal layer

Cells of inner layer

Spores

Elaters

Habitat

Distribution

\section{$1: 0.85-1.50(1.65)$}

plane, only on male bracts somewhat incurved backward

smooth or faintly crenulate due to jetting out of outer parts of marginal cells

yellow brown to purplish brown and carmine red

from densely to sparsely dentate-ciliolate

$1-5(6-8)-$ celled

(1) 2-4(6-10)-androus

$20-25$

3-5-stratose, (38) 45-78 mkm

23-40 x 40-75 mkm, with nodular stalked thickenings mainly on alterating longitudinal walls or on all longi- and latitudinal walls; occasionally nodular thickenings transforme into semiannular bands

(18) 23-38 x 70-120 mkm, with irregular, mostly complete. often branched semiannular bands

(17) 18-20(22) $\mathrm{mkm}$, punctate-areolate

mostly 2-spiral,

8-12(14) mkm in diam.

humus-covered rocks, decaying wood, bases of trees, among mosses on soil and in bogs

widespread, circumboreal
M. verrucosa ssp. verrucosa

M. v. ssp. nuda

oblong-lingulate to lingulate-falcate, the lower halves of leaves with subparallel sides (leaves are characte rized in natural state, i.e. dorsal margin is involuted, its width is not taken into account).

$1:(1.08) 1: 20-1.60(1.75)$

$1: 1.20-1.60$

strongly incurved to pipe-like involuted backward

smooth to distinctly-crenulate

mostly yellow brown, near ventral leaf base occasionally purplish brown, very rare purplish brown in distal halves of leaves

echinate smooth to coarsely crenulate

mostly yellow brown, near ventral leaf base occasionally purplish

smooth

dentate-ciliolate

1-5-celled

1-6-celled

1-5-androus

4-7-androus

17-18

(3) 4(5)-stratose, $40-50 \mathrm{mkm}$

18-30 x 40-90 mkm, character of thickenings as in $M$. taylorii

17-36 x 50-120 mkm, character of thickenings as in $M$. taylorii

14-18(19) mkm, punctate or finely areolate

mostly 2-spiral,

8-11(12) $\mathrm{mkm}$ in diam.

decaying wood, humus-covered rocks

southern Far East from Sakhalin to Yakushima I.

South Japan (Yakushima I.),Taiwan. 
distal parts of upper leaves was noted for $M$. verrucosa only once (...1958, Ponomarenko). It is quite possible that similar pigmentation sporadically occurs in $M$. nuda too.

Character of growth, density of leaves, their insertion and orientation on the stem. These features are variable, especially in $M$. taylorii. Densely leaved orthotropic plants may have subvertically oriented non-decurrent leaves, but lax plagiotropic forms have subhorizontally oriented, distinctly and rather longly, decurrent leaves. Using some of these characters, as well as cuticle and trigones structure, for differentiation of $M$. taylorii and $M$. verrucosa (Ladyzhenskaja \& Zenkova 1955; Hara 1956) is not warrant.

Character of perianth surface. This is a distinctive feature of $M$. verrucosa which distinguishes it from other species of the genus. Although the density and size of protuberances vary considerably, there are apparently no transitional forms in this respect between $M$. verrucosa and $M$. nuda.

Perianth mouth characters. These were used by different authors (Ladyzhenskaja \& Zenkova 1955; Inoue \& Yang 1966) for the differentiation of species of the genus. According to our observations, the perianth mouth structure of the given species is doubtfully distinctive because of its almost unpredictable plasticity. Though the length of cilia, in general, ranges greatly, for certain populations the range of its variability may be considerably less. So, the cilia in $M$. taylorii are often 1-4-celled, as in $M$. verrucosa. Their density may differ much between neighbouring plants of $M$. taylorii as in ...1939, Freiberg. The longest (4-8-celled) cilia of $M$. taylorii was found in plants of mod. angustifolia-colorata (...1948, Dylis). Although Inoue \& Yang (1.c.) described the cilia of perianth mouth of $M$. nuda as irregular in length, 2-6 cells long, plants of Inoue 14999 (mod. fulva) have perianth mouth with quite regular 1-2-celled teeth. More vigorous plants of $M$. nuda, mod. viridis (...1981, Lai), develop (2)3-4celled sparse cilia (Figs. 2,12,17).

Number of antheridia per bract. This used by Inoue \& Yang (l.c.) as a key feature for separating $M$. verrucosa and $M$. nuda. This character, however, is unstable but usually correlates with size of plants. Small male plants of $M$. taylorii develop (1) -2 antheridia per bract as it was noted by Grolle (1962), Schuster $(1959,1969)$, etc. But the robust ones often develop $2-4$, occasionally (as in coll. Kazanovsky 838) up to 8-10 antheridia per bract (in the last case, the antheridia differ considerably in their maturity). On the other hand, within the same androecium, 1-androus and empty bracts usually occur. Investigation of this criterion on the basis of herbarium material is rather difficult because of disintegration of antheridia. In view of this, we have had a limited possibility to revise it for $M$. verrucosa and $M$. nuda.

Sporophyte and spores. The absence of data on sporophyte of $M$. nuda prevents us from comparing it with the other two species. $M$. verrucosa has very similar sporophytic characters to $M$. taylorii (Tabl. 1). The most reliable character of the last species is obviously the spore size.

\section{RESULTS}

1. Mylia taylorii is a very polymorphous species with respect to the width/length leaf ratio and secondary pigmentation. Narrowleaved and yellow brown phenotypes of the species occur rather often throughout its range. In some regions the species is represented almost exclusively by such forms. Problematic plants from Khamar-Daban Range belong to $M$. taylorii.

2. Northern limit of distribution of $M$. verrucosa is the southern part of Russian Far East. Reports of the species from Chukotka (Schljakov 1979, ?Fig. 14 in Schljakov 1982; Afonina \& Duda 1987) are erroneous and based on narrow-leaved, yellow brown plants of $M$. taylorii.

3. The analysis of distinctive features of $M$. taylorii, $M$. verrucosa and $M$. nuda shows that $M$. verrucosa and $M$. nuda are very close vicarious taxa, occurring only in the South Far East and having similar ranges of morphological and ecological plasticity. There is only one reliable feature for 
their differentiation - character of perianth surface. $M$. taylorii differs from the other species of the section principally by the different leaf form, considerably wider morphological and ecological malleability as well as extensive range. Taking into account all these facts, it seems best to recognize $M$. nuda not as a distinct species but as a subspecies of $M$. verrucosa:

Mylia verrucosa Lindb. subsp. nuda (H. Inoue \& Yang) Potemk. \& Kazanovsky, comb. et stat. nov. - $M$. nuda H. Inoue \& Yang, 1966, Taiwania 12:35.

\section{KEY TO RECOGNIZED TAXA OF MYLIA}

1. Cuticle smooth; oil-bodies coarsely segmented, the individual segments protuberant; gemmiparous leaves modified, lanceolate, considerably narrowed to apex section ANOMALAE, M. anomala

1. Cuticle coarsely papillous; oil-bodies nearly smooth, formed by numerous small, non-protuberant globules; gemmiparous leaves (when present) similar to other leaves in form, never considerably narrowed to apex

section MYLIA (2)

2. Dorsal margin of sterile leaves plane; leaf margins in lower part oppositely curved, as an exception, subparallel and straight; purplish and purplish brown pigmentation of distal parts of leaves rather common for plants of insolated habitats; widespread

2. Dorsal leaf margin strongly incurved or involuted backward; lateral leaf sides in natural state (i. e. when dorsal margin incurved), subparallel and mostly somewhat falcate; purplish brown pigmentation of distal parts of leaves very rare; South Far East from Sakhalin to Taiwan .M. verrucosa s.l.(3)

3. Surface of perianth echinate - with numerous protuberances formed of several cells; from Sakhalin to Yakushima I. (South Japan)............... verrucosa subsp. verrucosa

3. Surface of perianth smooth; Yakushima I., Taiwan

M. verrucosa subsp. nuda
SPECIMENS EXAMINED. Mylia taylorii. R U S S I A: St.-Petersburg Prov., Yashchera River, 1988, Tscherepanov, LE; Murmansk Prov., 1927, SaviczLiubitzkaja, LE; South Siberia, Southern Baikal Region, Khamar-Daban Range, 1989-1991, Kazanorky 797 (per., $\sigma^{7}$ ), 800 (per., ơ) , 802, 808, 809, 815 (per., ơ), 838 (fr., $\left.\sigma^{7}\right), 931,992$ (fr.), $1078\left(\sigma^{7}\right), 1105$, IRK, LE (all these specimens are mod. viridis vel fulva; they were collected on decaying logs, only no. 838 - on wet humuscovered rocks); South Siberia, Sayan Mts., 1939, Dylis, LE; Far East, Norht Sichote-Alin', 1192 m. alt., 1948, Dylis, det. Abramova as M. verrucosa, LE (per., mod. angustifolia-purpureo-fusca); Far East, Khabarovsk Prov., Amgun' River, 1951, Orlov, LE (per., mod. viridis); Far East, Chukotka, Kuyvivecmkey River, 1981, Afonina, det. Duda as M. vernucosa, LE (mod. angustifolia-fulva). J A P A N: Yakushima I., 1951, Amakawa, LE (mod. fulva); Saitama County, Chichibu Mts., 1680 m.alt., 1952, Shimizu, LE (mod. Fulva); Saitama County, Chichibu Mts., 2000 m.alt., 1952, Shimizu, LE (mod. fulva). U. S. A: S.E. Alaska, Wrangell I., 1968, Worley 7781, LE; S.E. Alaska, Kuiu 1., 1968, Worley \& Schofield 9118, LE; S.E. Alaska, Kruzof 1., 1968, Worley \& Hamilton 9687, LE; New England, 1854, Sullivant, LE. C A N A D: British Colombia, Queen Charlotte Is., N.E. Graham I., 1967, Schofield 34772, LE (mod. subdensifolia-colorata trans. ad. mod. laxifolia-viridis): British Colombia, Queen Charlotte Is., Moresby I., 1971, Schofield 45040, LE; British Colombia, 7 miles N. of Port Clements, 1964, Schofield 23655, LE; Newfoundland, Avalon Peninsula, 1980, Brassard 13100, LE (mod. subangustifolia-fulva); East Coast of Hudson Bay, Long Island Sound, 1947, Kucyniak \& Tuomikoski T.1016, LE. U N I T E D K I N G D O M: Wales, 1964, Townsend, LE (mod. viridis vel. fulva); N. Yorkshire, 1964, Halliday, LE (mod. viridis). S W E D E N: Skane, Skaralid, Scheutz, LE (mod. angustifolia-fulva); Skane, Skaralid, i865, Hamnstroem, LE; Skane, Skaralid, 1911, Medelius, LE (mod. densifolia-purpureo-fusca trans. ad. mod. fulva); Scania, 1898, Lofvander, LE; Torne Lappmark, 1947, Arnell, LE; Bohuslan, 1882, Thedenius, LE; Vastmanland, 1966, Nyholm, LE (mod. angustifolia-laxifolia-fulva); Jamtland, 1905, Arnell, LE (mod. angustifolia-fulva trans. ad. mods. fusca et purpureo-fusca). N O RW A Y: Telemark, 1942, Stoermer, LE (mod. laxifoliaangustifolia-fulva). A U S T R I A: Salzburg, 1984, Krisai, LE; Salzburg, 1075 m.alt., 1944, Freiberg, LE (mod. fulva). G E R M N Y: Bavaria, 700 m.alt., 1939, Freiberg, LE (per., mods. viridis, fulva, subpurpurea). C H E C H I A: Bohemia bor., Krkonose Mts., 1967, Vana, LE (mod. angustifolia-viridis); Bohemia bor., 1972, Zemanova, LE; Bohemia orient., Police, 1970, Duda, LE (mod. viridis); Broumovske Steny Mts., Hvezda, 650 m.alt., 1970, Duda, LE (per., mod. viridis vel. subfulva); Broumovske Steny Mts., Bozenov, 650 m.alt., 1970, Duda, LE (mod. viridis); Broumovske Steny Mts., Suchy Duel, 600 m.alt., 1970, Duda, LE (per., $\sigma^{7}$, mod. anguistifolia-viridis vel. fulva); Brounovske Steny Mts., 650 m.alt., 1970, Duda, LE (per., mod. fulva); Silesia, Jeseniky Mt., 1000 m.alt., 1955, Duda, LE (mod. viridis); Silesia, Beskydy Mt., 1000 m.alt., 1956, Duda, LE (mod. viridis); Silesia, Beskydy Mt., 700 m.alt., 1950, Duda, LE (mod. fulva); Silesia, Beskydy Mt., 1000 m.alt., 1950, Duda, LE (mod. fulva); Silesia, Beskydy Mt., 1067 m.alt., 1956, Duda, LE (per., mod. fulva); S L O V A K I A: Mala 


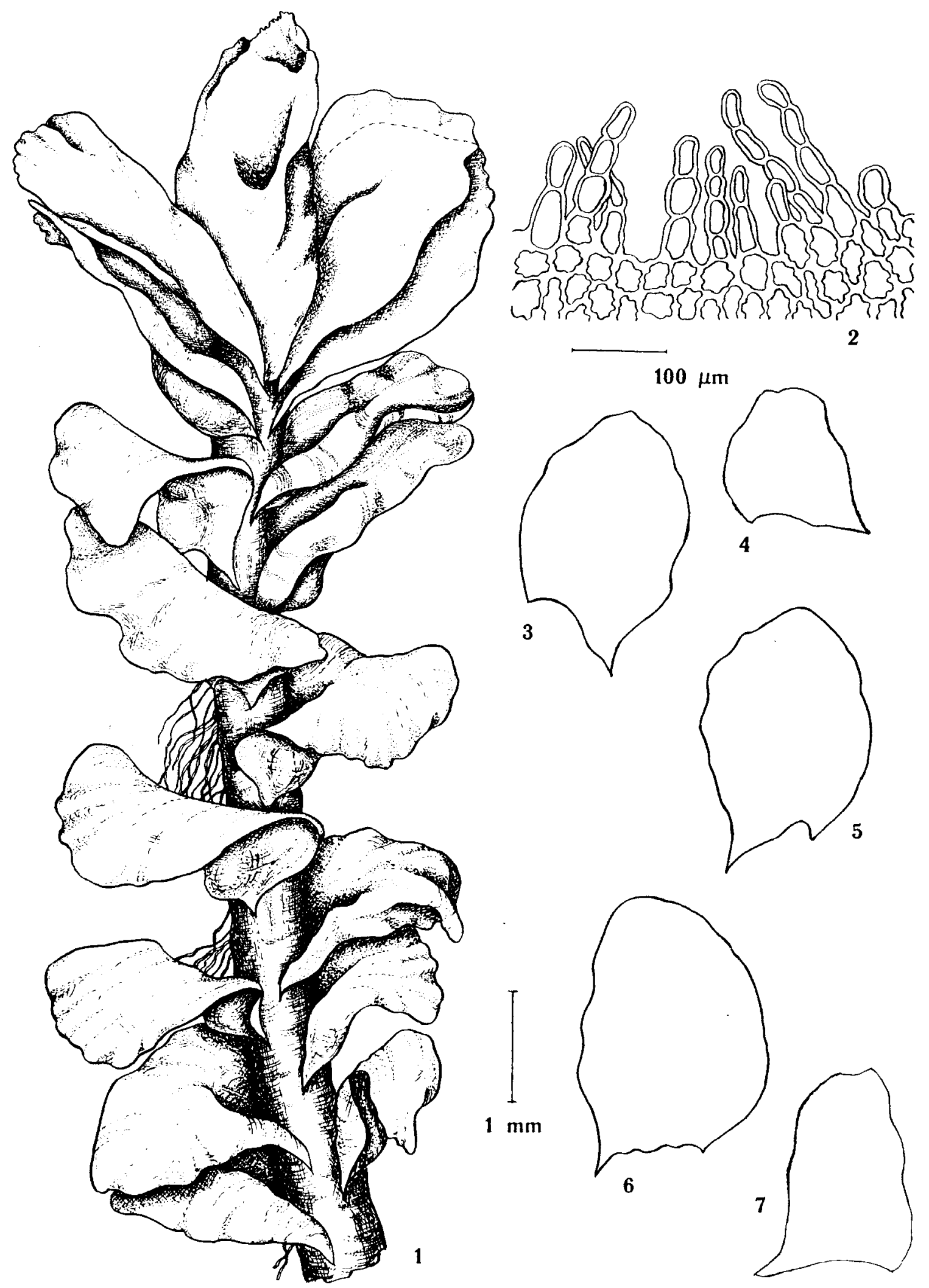



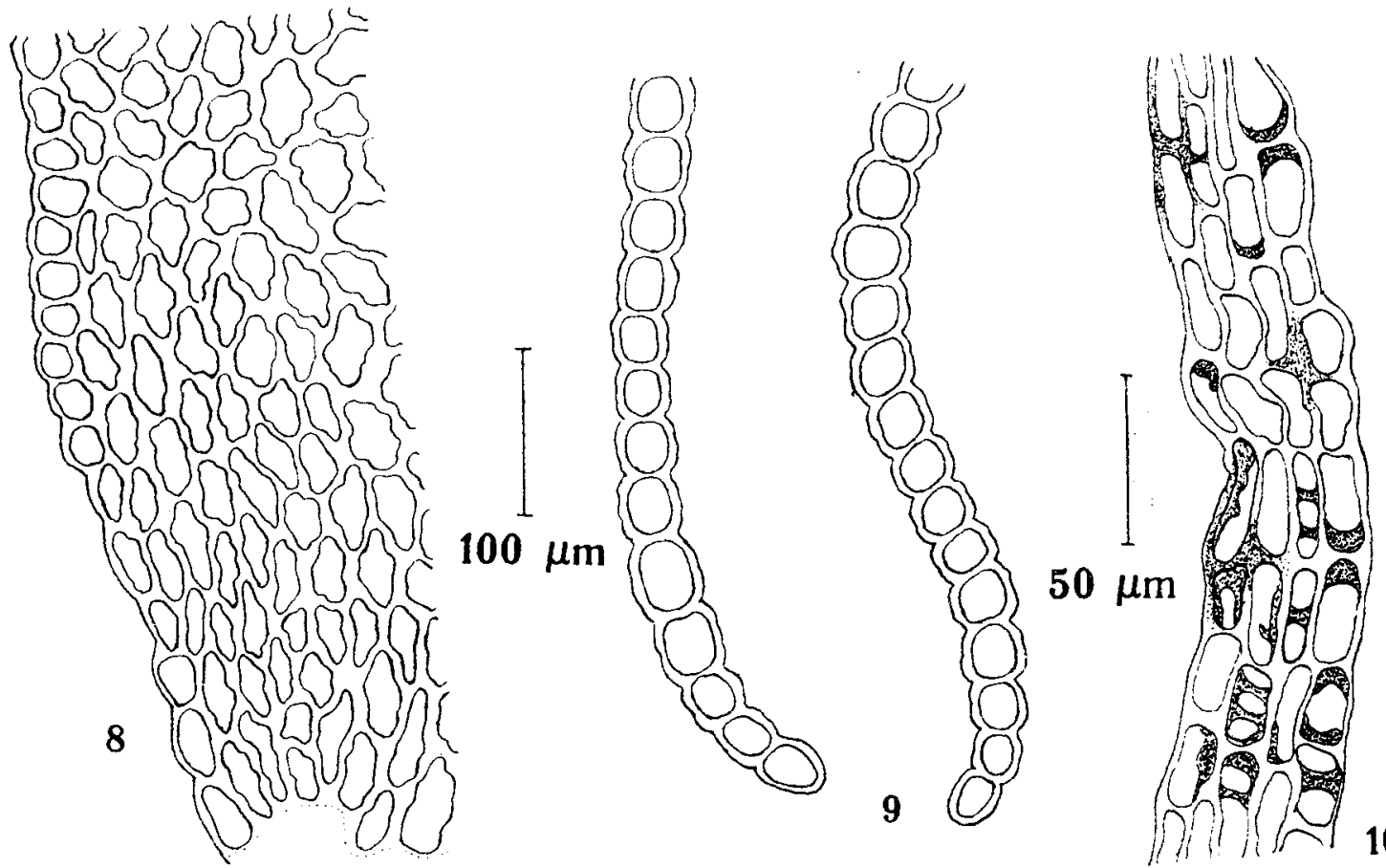

Figs. 1-7. Mylia taylorii (Hook.) S. Gray. 1. Plant with perianth; 2. Part of perianth mouth; 3-7. Leaves (1,2 from Kazanovsky 838; 3,5,6 - from Kazanovsky 808; 4 - from ...1000 m.alt, 1956, Duda; 7 - from ...1959, Wojterski). Scale bars: $1 \mathrm{~mm}$ - for $1,3-7 ; 100 \mathrm{mkm}$ - for 2 .

Figs. 8-10. Mylia taylorii (Hook.) S. Gray. 8. Basal part of ventral leaf margin; 9. Cross sections of dorsal leaf margin (all from Kazanovsky 838); 10 . Cross section of capsule wall. Scale bars: $100 \mathrm{mkm}-$ for $8-9 ; 50 \mathrm{mkm}-$ for 10 .

Tatra Mts., 1935, Pilous, LE; Tatra Magna Mts., 13001400 m.alt., 1955, Boros, LE (gemm, mod. viridis vel. colorata); Rohace Mt:., 1600 m.alt., 1960, Duda, LE. P O L A N D: Pilsko Mt., 1275 m.alt., 1959, Wojterski, LE (mod. angustifolia-viridis vel. subfulva); Tatry Zachodnie Mts., 1725 m.alt., 1958, Szweykowski, LE (per., mod. viridis vel. colorata); Babia Gora, 1140 m.alt., 1954, Wojterski, LE; Gory Stolowe w Kotlinie Klodzkiej, 1952, Szweykowski, LE (mod. viridis).

Mylia verrucosa. R U S S I A (FAR EAST - Primorye Territory): Chuguevsky Distr., Snezhnaya Mt., 1977, Bardunov \& Cherdantzeva, IRK, LE (fr.); Chuguevsky Distr., Snezhnaya Mt., 1977, Bardunov, IRK, LE (fr.); Chuguevsky Distr., Spring Berezovyi, 1976, Gambaryan, LE (fr.); Chuguevsky Distr., Pravaya Sokolovka Creek, 1976, Gambaryan, IRK, LE (fr.); Lazovsky Reserve, 1974, Cherdantzeva \& Bardunov, IRK, LE (per.); Lazovsky Pass, 1974, Bardunov \& al., IRK, LE (fr.); South Sichote-Alin' Range, Tri Sestry Mt., 1430 m.alt., 1958, Ponomarenko, LE (per., incl. mod. latifolia-purpureo-fusca); South Sichote-Alin' Range, Tri Sestry Mt., 1430 m.alt., 1959, Ponomarenko, LE (per.); South Sichote-Alin' Range, Tzkhamodynza Mt., 1580 m.alt., 1959, Ponomarenko, LE (per); North SichoteAlin' Range, Botch River, 1924, Savicz, LE (per.). J A P A N: Sikoku, Ehime, 1947, Ochi, LE (per.).

Mylia nuda. T A I W A N: Ali Mt., 2300 m.alt.,
Oct. 28, 1966, Inoue 14999, JE (per., $\sigma^{\gamma}$, mod. fulva) (the specimen is labelled as isotype but probably it is a topotype, since the type had different coll. No (18590) and altitude $(2200 \mathrm{~m})$, (Inoue \& Yang 1966)); Ilan Co., Yuenyang Lake Nat. Reserve, 1650 m.alt., March 6, 1981, Lai, ALA (per., mod. viridis).

\section{ACKNOWLEDGEMENTS}

We express our sincere thanks to B. M. Murray and L. V. Bardunov for reading the first version of the manuscript and offering several valuable comments. Our deep gratitude is due to $\mathrm{L}$. V. Bardunov and $S$. $K$. Gambaryan who provided colections of Mylia verrucosa for our study and $R$. Grolle who sent us authentic specimen of $M$. nuda. We are much indebted to $S$. K. Cherepanov for nomenclatural assistance and to A. Oskol'sky for his kind help with Latin translation of the discription. The English was corrected by B. C. Tan. The study was financially supported by scholarship of J. Soros Fund. 

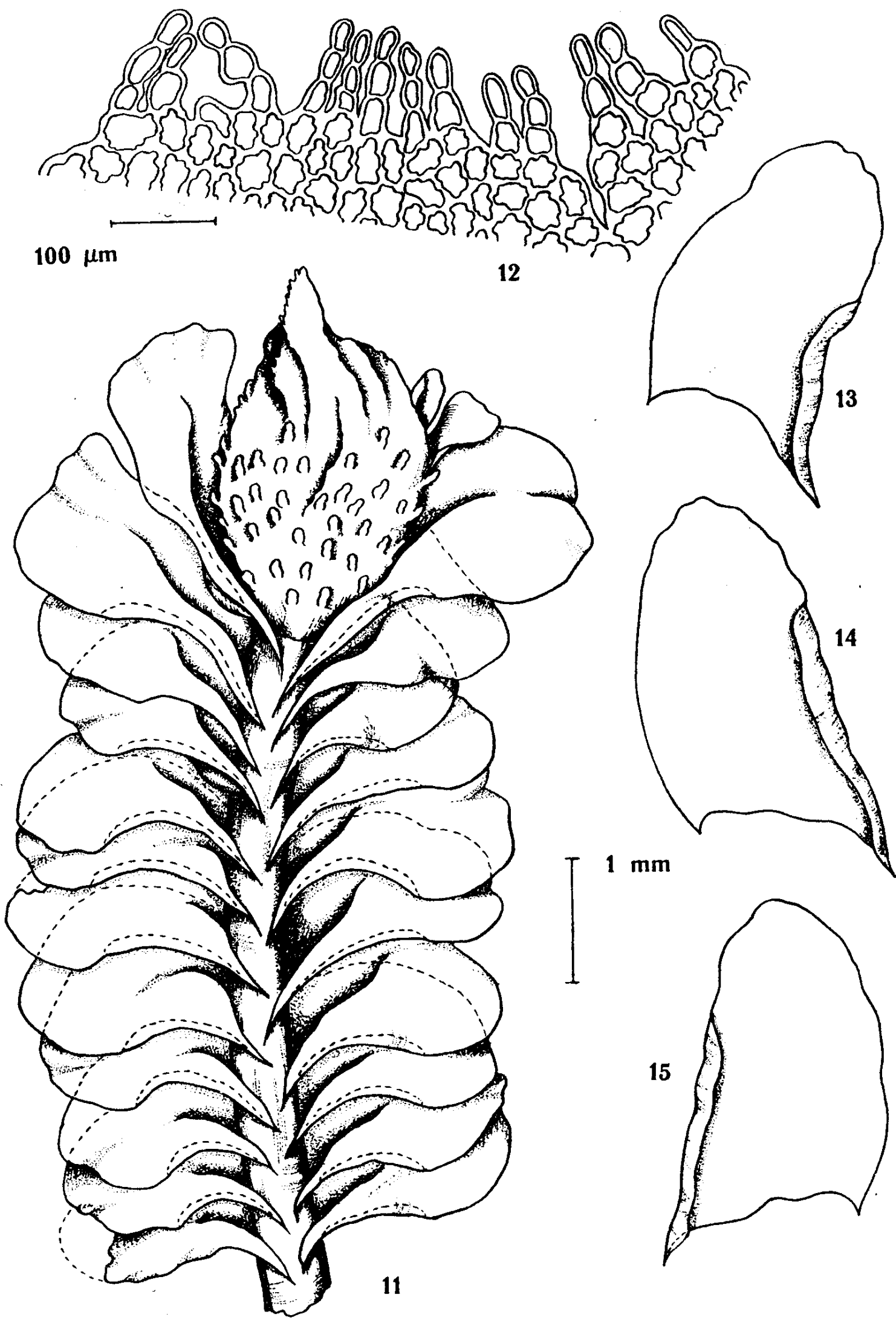

Figs. 11-15. Mylia verrucosa Lindb. subsp. verrucosa. 11. Plant with perianth; 12. Part of perianth mouth; 13-15. Leaves (all from ... 1977, Bardunov). Scale bars: $1 \mathrm{~mm}$ - for 11, 13-15; $100 \mathrm{mkm}$ - for 12. 


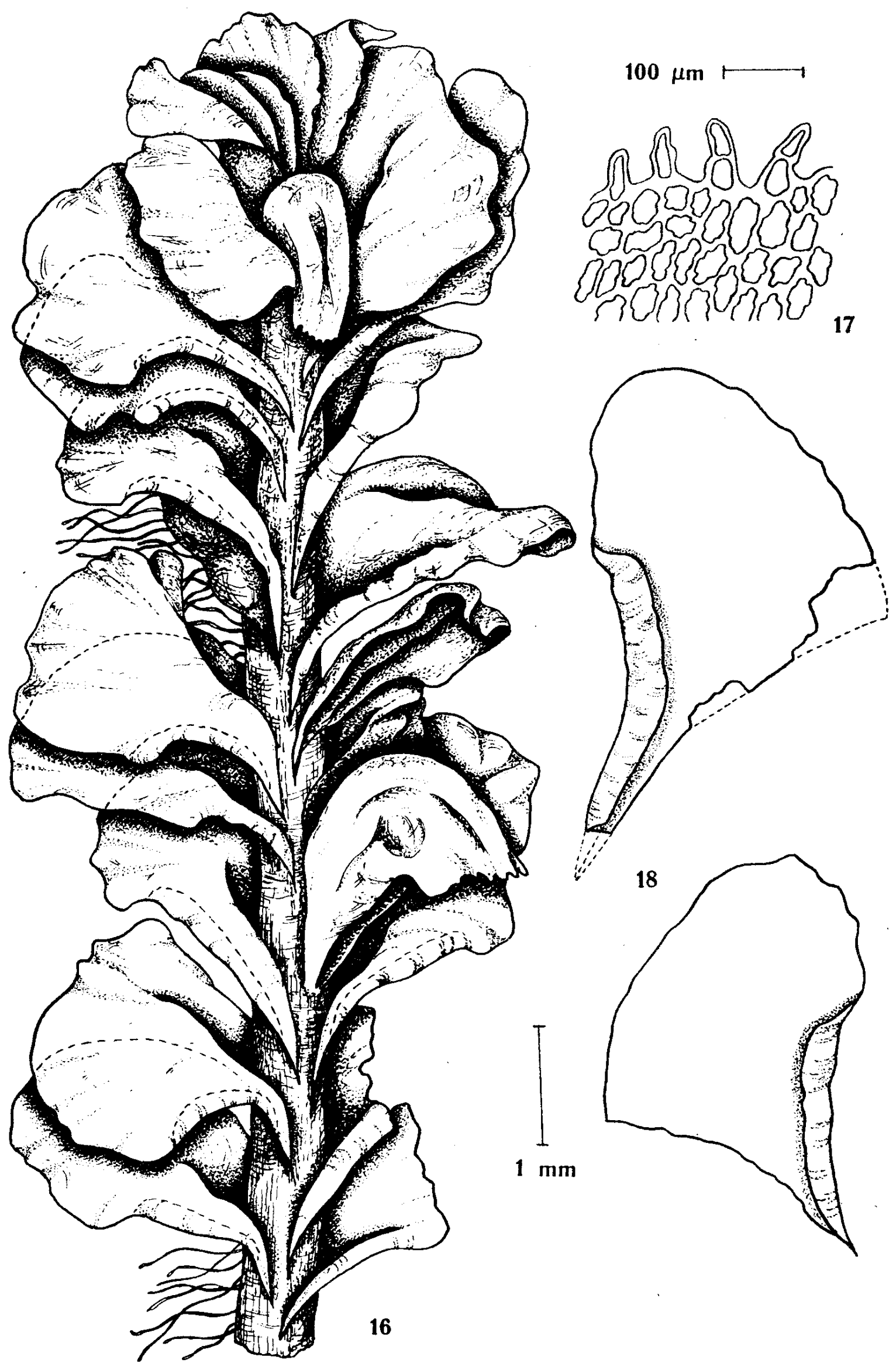

Figs. 16-18. Mylia verrucosa Lindb. subsp. nuda (H. Inoue \& Yang) stat. nov. 16. Plant with perianth; 17. Part of perianth mouth; 18. Leaves (all from Inoue 14999), Scale bars: $1 \mathrm{~mm}$ - for 16, 18; $100 \mathrm{mkm}-$ for 17 . 

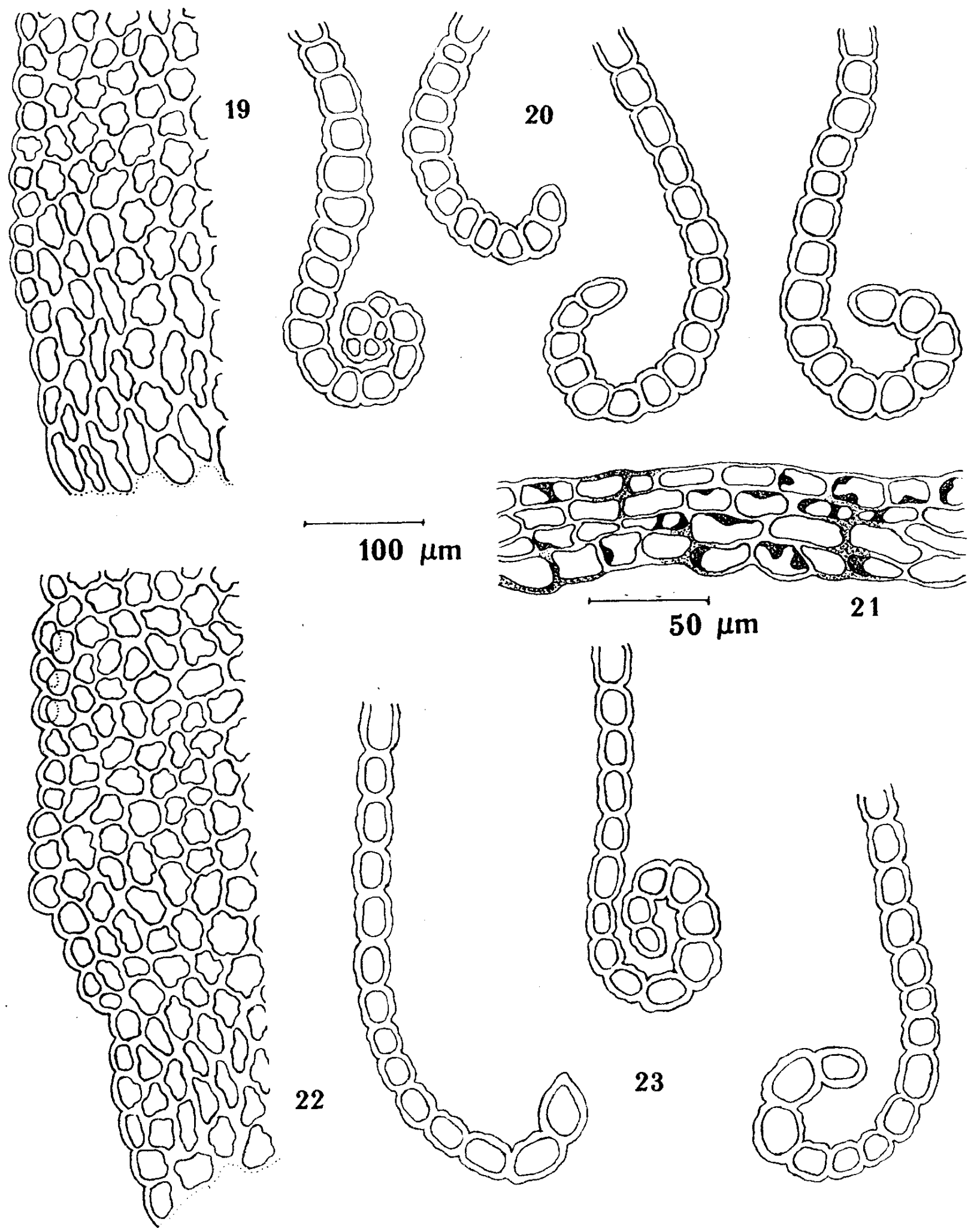

Figs. 19-23. Mylia verrucosa Lindb. subsp. verrucosa and subsp. nuda (H. Inoue \& Yang) stat. nov. 19-21. Subsp. verrucosa (from ... 1977, Bardunov): 19. Basal part of ventral leaf margin; 20. Cross sections of dorsal leaf margin; 21. Cross section of capsule wall; 22,23. Subsp. nuda (from Inoue 14999): 22: Basal part of ventral leaf margin; 23. Cross sections of dorsal leaf margin. Scale bars: $100 \mathrm{mkm}$ - for 19-20, 22-23; $50 \mathrm{mkm}-$ for 21 . 


\section{REFERENCES}

AFONINA, O. M. \& J. DUDA [AФOHИНA O. M. \& म. ДУДА] 1987. Contributions to the flora of hepatics of Anadyr River Basin, 2. - [Материалы $k$ флоре печеночных мхов бассейна реки Анадырь, 2]. Nowosti Sist. Nizsh Rast. [HoهOcmu cucm. rusu. pacm.] 24: 193-197.

GRAY, S. F. 1821. A Natural Arrangement of British Plants. London, 1: $i-x x v i i i, 1-824$.

GROLLE, R. 1962. Monographie der Lebermoosgattung Leptoscyphus Mitt. - Nova Acta Leopoldina, N.F. 25 (161): 1-143.

HARA, M. 1956. Revision of the family Jungermanniaceae in Sikoku, southern Japan (1). - Res. Rep. Kochi Univ. 5(33): 1-9.

INOUE, H. \& B. YANG 1966. The genus Mylia in Taiwan. - Taiwania 12: 35-37.

LADYZHENSKAJA, K. I. \& E. JA. ZENKOVA [ЛАДЫЖЕНСКАЯ К. И., Е. Я. ЗЕНКОВА] 1955. On the ecology of the genus Mylia Gray in USSR. - [K экологии рода Mylia Gray в CCCP]. Bot. Mat. Otd. Spor. Rast. Bot. Inst. Akad. Nauk SSSR [Bom Mamep. Omd. Cnop. Pacm. Bom. HH-ma AH CCCPI 10: 231-240.
LINDBERG, S. O. 1872. Contributio ad floram cryptogamam Asiae Boreali-Orientalis. - Acta Soc. Sci. Fennica 10: 223-280.

SCHIJAKOV, R. N. [ШUЛЯKOB P. H.] 1979. New contributions to the hepatic flora of the North of the USSR. - [Новые дополнения $x$ флоре печеночников северных районов CCCP]. Novosti Sist. Nizsh. Rast. [Hoвоcmu cucm. rusu. pacm.] 16: 201 -208.

SCHIJAKOV, R. N. [HJGKOB P. H.] 1982. The hepatics of the North of the USSR, Vol. 5. [Печеночные мхи Севера СССР, Т. 5 ]. Leningrad, Nauka [J.: Hayka],.196.

SCHUSTER, R. M. 1959. A Monograph of the Nearctic Plagiochilaceae. Part 1. Introduction and Sectio 1. Asplenioides. - Amer. MidL Nat. 62(1): 1-166.

SCHUSTER, R. M. 1969. The Hepaticae and Anthocerotae of North America east of the hundredth meridian. - New York - London, Columbia Univ. Press 2, 1062.

VANA, J. \& H. INOUE 1983. Studies in Taiwanian Hepaticae 5. Jungermanniaceae. - Bull Natn. Sci. Mus., Ser. B, 9(4): 125-142. 